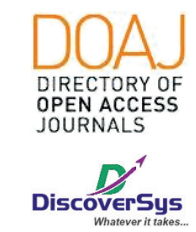

Published by DiscoverSys

\title{
Gambaran pemeriksaan serologi, darah lengkap, serta manifestasi klinis demam berdarah dengue pasien dewasa di RSUP Sanglah Denpasar periode Januari sampai Desember 2016
}

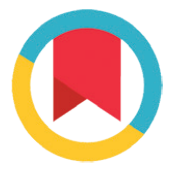

CrossMark

\author{
Ni Made Stithaprajna Pawestri, ${ }^{1 *}$ D.G.D. Dharma Santhi, ${ }^{2}$ A.A. Wiradewi Lestari ${ }^{2}$
}

\section{ABSTRACT}

Background: A serological test of anti-dengue, complete blood count $(C B C)$, and clinical manifestations routinely assesed in patients with dengue hemorrhagic fever (DHF).

Aim: This study aimed to determine the description of the serological test, the CBC test, and clinical manifestations of DHF.

Method: Research design used cross-sectional descriptive study with the non-experimental retrospective method, using medical records data of adult DHF patients at Sanglah Hospital Denpasar. The sample of the study was adult DHF impatient from January to December 2016. Result and Conclusion: Of the 110 samples, the study revealed 71 (65\%) men and 39 (35\%) women. As from serology, 16 (14,5\%) primary infection and $94(85,5 \%)$ secondary infection were detected.
$\mathrm{CBC}$ test results in both primary and secondary infections showed variative value. Some of the variables with the highest number of samples in abnormal value were thrombocytes (decreased, $100 \%$ both primary and secondary infection), as against in leucocytes (decreased, $81.25 \%$ in primary infection, $48.94 \%$ in secondary infection). Haematocrit is normal for both infections. Clinical manifestations were varied such as fever and torniquet (+) are most prominent (100\% both primary and secondary infections), the most prominent bleeding is in the gums (75\% in primary infection, $57.69 \%$ in secondary infection), and the other clinical sign such as hepatomegaly, pleural effusion, hypoalbuminemia, cold skin, restlessness, and shock were rare observed.

Keywords: Anti-dengue serology, tropical disease, dengue fever

Cite This Article: Pawestri, N.M.S., Santhi, D.G.D.D. Lestari, A.A.W. 2020. Gambaran pemeriksaan serologi, darah lengkap, serta manifestasi klinis demam berdarah dengue pasien dewasa di RSUP Sanglah Denpasar periode Januari sampai Desember 2016. Intisari Sains Medis 11(2): 856-860. DOI: 10.15562/ism.v11i2.222

\section{ABSTRAK}

Pemeriksaan serologi anti dengue, darah lengkap, dan klinis mutlak dilakukan pada pasien demam berdarah dengue (DBD).

Tujuan: Penelitian ini dilakukan untuk mengetahui gambaran pemeriksaan serologi, darah lengkap dan manifestasi klinis.

Metode: Rancangan penelitian descriptive cross-sectional dengan metode retrospektif non-eksperimental, menggunakan data rekam medis pasien DBD dewasa di RSUP Sanglah Denpasar. Sampel penelitian adalah 110 pasien DBD dewasa rawat inap periode Januari-Desember 2016.

Hasil dan Kesimpulan: Dari 110 sampel didapatkan 71 (65\%) lakilaki dan 39 (35\%) perempuan. Dari pemeriksaan serologi, didapatkan $16(14,5 \%)$ pasien infeksi primer dan 94 (85,5\%) infeksi sekunder. Hasil pemeriksaan darah lengkap baik pada infeksi primer maupun sekunder menunjukkan semua variabel memiliki nilai yang bervariasi. Beberapa variabel dengan jumlah sampel paling banyak pada nilai tidak normal yaitu trombosit (menurun, 100\% baik infeksi primer maupun sekunder), leukost (menurun, 81,25\% pada infeksi primer, 48,94\% pada infeksi sekunder), hematokrit cenderung normal pada kedua infeksi, manifestasi klinis yang bervariasi, demam dan torniquet (+) yang paling menonjol (100\% baik infeksi primer maupun sekunder). Selain itu, perdarahan yang paling menonjol adalah pada gusi (75\% pada infeksi primer, 57,69\% pada infeksi sekunder). Klinis lain seperti hepatomegali, efusi pleura, hipoalbuminemia, kulit dingin, gelisah dan syok jarang teramati.
${ }^{2}$ Bagian/SMF Patologi Klinik Fakultas Kedokteran Universitas Udayana/Rumah Sakit Umum Pusat Sanglah

\section{${ }^{*}$ Correspondence to:}

Ni Made Stithaprajna Pawestri, Program Studi Pendidikan Dokter, Fakultas Kedokteran, Universitas

Udayana

dektitamade@gmail.com

Diterima: 08-04-2018

Disetujui: 08-08-2018

Diterbitkan: 01-08-2020

Kata kunci: serologi anti dengue, penyakit tropis, demam dengue

Cite Pasal Ini: Pawestri, N.M.S., Santhi, D.G.D.D. Lestari, A.A.W. 2020. Gambaran pemeriksaan serologi, darah lengkap, serta manifestasi klinis demam berdarah dengue pasien dewasa di RSUP Sanglah Denpasar periode Januari sampai Desember 2016. Intisari Sains Medis 11(2): 856-860. D0l: 10.15562/ism.v11i2.222

\section{PENDAHULUAN}

Infeksi dengue disebabkan oleh virus dengue dan ditularkan melalui perantara gigitan nyamuk. ${ }^{1}$ DBD memiliki insiden 50-100 juta yang dilaporkan di lebih dari 100 negara. ${ }^{2}$ Jumlah pasien DBD dari tahun ke tahun terus meningkat. Pada tahun 2014 tercatat penderita DBD di 34 provinsi di Indonesia 
sebanyak 71.668 orang, dan 641 diantaranya meninggal dunia. ${ }^{3}$ Bali merupakan provinsi dengan kasus DBD terbanyak keempat di Indonesia, dengan angka insiden pada tahun 2014 mencapai 201,2 per 100.000 penduduk. ${ }^{4}$ Menurut World Health Organization (WHO) tahun 2011, infeksi dengue dibedakan menjadi asimtomatik dan simtomatik. Infeksi simtomatik dibagi lagi menjadi undifferentiated fever, demam dengue (DD), demam berdarah dengue (DBD), dan expanded dengue syndrome (isolated organopathy). DBD dibedakan lagi menjadi empat derajat menurut tingkat keparahannya. Fase DBD meliputi fase demam, fase kritis, dan fase penyembuhan. ${ }^{5}$ Diagnosis DBD ditegakkan jika terdapat demam tinggi mendadak tanpa sebab yang jelas dan berlangsung 2-7 hari, dengan paling tidak tambahan 2 dari kriteria berikut: manifestasi perdarahan (uji bendung positif, petechie, purpura, ecchymosis, epistaksis, perdarahan gusi, hematemesis, dan atau melena), hepatomegali, trombositopenia (trombosit $\leq 100.000 / \mu \mathrm{l}$ ), tanda perembesan plasma (peningkatan hematokrit $\geq 20 \%$ normal, efusi pleura, dan hipoalbuminemia). ${ }^{6}$

Penegakan DBD meliputi anamnesis, pemeriksaan fisik, dan pemeriksaan penunjang. Dari anamnesis dan pemeriksaan fisik, dapat diketahui manifestasi klinis DBD. Pemeriksaan penunjang yang umum dilakukan adalah pemeriksaan serologi IgM dan IgG, serta pemeriksaan darah lengkap. Dari pemeriksaan serologi IgM dan IgG, dapat diketahui jenis infeksinya, apakah infeksi primer atau infeksi sekunder. Dari pemeriksaan darah lengkap, ada banyak parameter yang dapat dilihat, pada umumnya trombosit, hematokrit, dan leukosit Penelitian ini bertujuan untuk mengetahui gambaran jenis infeksi (primer atau sekunder) dari pemeriksaan serologi, selanjutnya melihat

Tabel 1 Gambaran Sampel Jenis Kelamin dan Usia

\begin{tabular}{llcc}
\hline Variabel & & Jumlah (orang) & Persen (\%) \\
\hline Jenis & Laki-laki & 71 & $65 \%$ \\
Kelamin & Perempuan & 39 & $35 \%$ \\
Usia & $25-35$ & 75 & $68,2 \%$ \\
(tahun) & $36-45$ & 35 & $31,8 \%$ \\
\hline
\end{tabular}

Tabel 2 Gambaran Jumlah dan Presentase $\lg M(+), \lg G(+), \lg M$ dan IgG (+) serta Pembagian Jenis Infeksinya

\begin{tabular}{llcc}
\hline Variabel & & Jumlah (orang) & Persen (\%) \\
\hline Serologi IgM dan IgG & $\operatorname{IgM}(+)$ & 16 & $14,5 \%$ \\
& $\operatorname{IgG}(+)$ & 81 & $73,6 \%$ \\
& $\operatorname{IgM}$ dan IgG (+) & 13 & $11,8 \%$ \\
\multirow{2}{*}{ Serologi IgM dan IgG } & Infeksi primer & 16 & $14,5 \%$ \\
& Infeksi sekunder & 94 & $85,5 \%$ \\
\hline
\end{tabular}

gambaran darah lengkap dan manifestasi klinis baik dari infeksi primer maupun infeksi sekunder.

\section{METODE}

Rancangan penelitian yang digunakan adalah descriptive cross sectional. Pengambilan sampel dilakukan secara retrospective non-experimental, dengan menggunakan seluruh data rekam medis pasien DBD usia dewasa (26-45 tahun) dengan hasil pemeriksaan serologi IgM dan IgG, hasil pemeriksaan darah lengkap, dan manifestasi klinis yang dirawat inap di RSUP Sanglah Denpasar periode Januari-Desember 2016. Teknik pengambilan data dilakukan dengan metode consecutive sampling. Pasien dikatakan suspect DBD, jika hasil pemeriksaan serologi positif, ditambah munculnya gejala DBD menurut WHO 2011. Data yang digunakan yaitu data hasil pemeriksaan serologi pada hari ketujuh, dan data hasil pemeriksaan darah lengkap pada hari kelima. Analisis data dilakukan secara deskriptif dengan bantuan perangkat lunak Microsoft Excel 2007 untuk mengetahui gambaran sampel berdasarkan jenis infeksinya, serta gambaran pemeriksaan darah lengkap dan manifestasi klinis berdasarkan jenis infeksinya.

\section{HASIL}

Pada penelitian ini, diperoleh sebanyak 110 sampel periode bulan Januari-Desember 2016, dengan jumlah sampel terbanyak pada bulan April yaitu sebanyak $29(26,36 \%)$ sampel. Sampel terdiri atas 71 (65\%) pasien laki-laki dan 39 (35\%) pasien perempuan. Sampel terdiri atas pasien DBD usia dewasa, yang merupakan gabungan dari usia dewasa awal (25-35 tahun) dan dewasa akhir (26-45 tahun) berdasarkan kelompok usia menurut Departemen Kesehatan RI. Hasilnya didapatkan usia dewasa awal sebanyak $75(68,2 \%)$ pasien, dan usia dewasa akhir sebanyak $35(31,8 \%)$ pasien.

Pada hasil pemeriksaan serologi sampel, diperoleh nilai IgM positif, nilai IgG positif, serta IgM dan IgG positif. Selanjutnya dikelompokkan menjadi jenis infeksinya. Infeksi primer apabila hanya IgM yang positif, sedangkan infeksi sekunder apabila IgG positif, maupun IgM dan IgG positif. Hasilnya seperti yang ditunjukkan pada tabel 2 .

Pada hasil pemeriksaan darah lengkap sampel, dicari mean (nilai rerata), standar deviasi (SD), median (nilai tengah), min (nilai terendah), dan max (nilai tertinggi) dari masing-masing jenis infeksi, baik infeksi primer maupun infeksi sekunder. Hasilnya seperti yang digambarkan pada Tabel 3.

Tabel 4 menunjukkan bahwa semua sampel mengalami penurunan nilai trombosit, sebagian 
Tabel 3 Kondisi, mean, median, SD, min dan max hasil pemeriksaan darah lengkap sampel menurut jenis infeksinya

\begin{tabular}{lcccccc}
\hline Variabel & Jenis Infeksi & Mean & SD & Median & Min & Max \\
\hline Trombosit (platelet) $\left(\times 10^{3} /\right.$ & Primer & 67,44 & 20,21 & 73,13 & 16,00 & 92,49 \\
$\mu \mathrm{L})$ & Sekunder & 59,57 & 31,37 & 57,72 & 7,03 & 149,10 \\
Hematokrit $(\mathrm{HCT})(\%)$ & Primer & 42,48 & 3,21 & 48,71 & 41,76 & 53,01 \\
& Sekunder & 47,19 & 4,98 & 47,20 & 33,07 & 53,43 \\
Leukosit $\left(\times 10^{3} / \mu \mathrm{L}\right)$ & Primer & 3,08 & 1,01 & 2,91 & 1,49 & 5,20 \\
& Sekunder & 4,62 & 3,04 & 3,92 & 1,38 & 25,30 \\
\hline
\end{tabular}

Tabel 4 Gambaran sampel berdasarkan hasil pemeriksaan darah lengkap

\begin{tabular}{lcccc}
\hline Variabel & Jenis Infeksi & Meningkat & Normal & Menurun \\
\hline Trombosit & Primer & $0(0 \%)$ & $0(0 \%)$ & $16(100 \%)$ \\
& Sekunder & $0(0 \%)$ & $0(0 \%)$ & $94(100 \%)$ \\
Hematokrit & Primer & $2(12,5 \%)$ & $14(87,5 \%)$ & $0(0 \%)$ \\
& Sekunder & $16(17,0 \%)$ & $77(81,9 \%)$ & $1(1,1 \%)$ \\
Leukosit & Primer & $0(0 \%)$ & $3(18,75 \%)$ & $13(81,25 \%)$ \\
& Sekunder & $3(3,19 \%)$ & $45(47,87 \%)$ & $46(48,94 \%)$ \\
\hline
\end{tabular}

Tabel 5 Gambaran manifestasi klinis sampel berdasarkan jenis infeksi

\begin{tabular}{lcccc}
\hline Manifestasi Klinis & Infeksi Primer & Persentase (\%) & Infeksi Sekunder & Persentase (\%) \\
\hline Demam & 16 & $100 \%$ & 94 & $100 \%$ \\
Uji Torniquet & 16 & $100 \%$ & 94 & $100 \%$ \\
Perdarahan & 4 & $25 \%$ & 52 & $55,32 \%$ \\
Hepatomegali & 0 & $0 \%$ & 12 & $12,77 \%$ \\
Efusi Pleura & 0 & $0 \%$ & 1 & $1,06 \%$ \\
Hipoalbuminemia & 0 & $0 \%$ & 1 & $1,06 \%$ \\
Sianosis mulut & 0 & $0 \%$ & 0 & $0 \%$ \\
Kulit dingin \& lembab & 0 & $0 \%$ & 1 & $1,06 \%$ \\
Gelisah & 0 & $0 \%$ & 0 & $0 \%$ \\
Gejala syok & 0 & $0 \%$ & 1 & $1,06 \%$ \\
\hline
\end{tabular}

besar sampel menunjukkan nilai normal pada HCT, dan sebagian besar sampel memiliki jumlah leukosit menurun.

Tabel 5 menunjukkan bahwa gejala demam dan uji torniquet muncul di semua sampel, baik infeksi primer maupun infeksi sekunder. Perdarahan juga muncul baik di infeksi primer maupun infeksi sekunder, namun tidak pada semua sampel. Manifestasi klinis lain seperti hepatomegali, efusi pleura, hipoalbuminemia, kulit dingin dan lembab, serta gejala syok hanya muncul di infeksi sekunder. Sianosis mulut dan gelisah tidak muncul di kedua infeksi.

\section{DISKUSI}

Pada penelitian ini didapatkan bahwa jumlah sampel paling banyak adalah pada bulan April. Hal ini dikarenakan kondisi lingkungan pada bulan
April-Mei mendukung perkembangan dari nyamuk Aedes aegypti, dimana sudah dimulainya musim peralihan, namun hujan masih sering melanda. ${ }^{7}$

Berdasarkan jenis kelamin, jumlah sampel berjenis kelamin laki-laki lebih banyak dibandingkan perempuan. Hal ini sesuai dengan data yang terdapat pada Profil Kesehatan Provinsi Bali tahun 2014, dimana pada statistik tersebut diketahui bahwa pada kasus demam berdarah dengue lebih banyak pasien laki-laki $(55,3 \%)$ dibandingkan pasien perempuan $(44,7 \%)$. Jika dilihat dari komposisi penduduk Provinsi Bali tahun 2014, diketahui populasi laki-laki lebih banyak dibandingkan perempuan. ${ }^{8}$

Distribusi jumlah sampel berdasarkan pemeriksaan serologi IgM-IgG menunjukkan bahwa IgG (+) memiliki jumlah terbanyak, bahkan dibandingkan dengan IgM $(+)$. Nilai IgG yang positif menandakan bahwa host pernah terjangkit sebelumnya 
atau mengalami infeksi berulang. Ini berarti infeksi sekunder lebih banyak dibandingkan dengan infeksi primer. Hal ini kemungkinan disebabkan karena infeksi sekunder umumnya menimbulkan gejala yang lebih berat hingga mengarah ke Sindrom Syok Dengue (SSD), sehingga angka rawat inapnya lebih tinggi. Sementara infeksi primer seringkali bersifat subklinis, sehingga lebih sedikit angka rawat inapnya. Kurangnya pengetahuan masyarakat mengenai infeksi DBD menjadi penyebabnya, sehingga kasus baru menjadi jarang ditemukan. ${ }^{5}$

Dari seluruh sampel yang didapat, baik sampel infeksi primer maupun infeksi sekunder, mengalami kondisi trombositopenia, yaitu penurunan jumlah trombosit kurang dari jumlah normal terendah. Jumlah normal trombosit berkisar antara $150 \times 10^{3} /$ $\mu \mathrm{L}-450 \times 10^{3} / \mu \mathrm{L}$. Trombositopenia pada penderita DBD diduga terjadi akibat peningkatan destruksi trombosit oleh sistem retikuloendotelial, agregasi trombosit akibat endotel vaskuler yang rusak serta penurunan produksi trombosit oleh sumsum tulang. ${ }^{9}$ Penurunan trombosit pada pasien demam berdarah dengue sangat umum terjadi. Di hari ke 3-8 penurunan dapat terjadi hingga mencapai $100 \times 10^{3} / \mu \mathrm{L}$ dan bisa terus berlanjut hingga mencapai $<100 \times 10^{3} / \mu \mathrm{L}$. Namun dikatakan pada hari ke 6-7 sebenarnya jumlah trombosit sudah meningkat secara perlahan dan nilainya menjadi normal kembali pada hari ke 8-10. ${ }^{5}$ Pada penelitian ini digunakan data hasil pemeriksaan darah lengkap hari ke-5, oleh karena itulah semua sampel masih memiliki nilai trombosit yang menurun. Trombositopenia juga merupakan salah satu syarat pasien ke dalam demam berdarah dengue menurut WHO $2011 .^{6}$

Nilai normal hematokrit (HCT) dewasa berbeda sesuai jenis kelamin. Laki-laki memiliki rentang nilai hematokrit $41-53 \%$, sedangkan perempuan $36-46 \%$. Baik infeksi primer maupun sekunder diperoleh sampel dengan nilai HCT normal yang paling banyak, akan tetapi pada infeksi sekunder didapatkan sampel yang mengalami peningkatan nilai HCT jauh lebih banyak dibandingkan pada infeksi primer. Ini disebabkan karena infeksi sekunder merupakan infeksi berulang yang berisiko menimbulkan komplikasi yang serius, sehingga akan memunculkan gejala yang lebih parah. ${ }^{5}$ Karena lebih banyak pasien memiliki nilai HCT normal, sehingga manifestasi klinis SSD belum dapat ditemukan pada sampel penelitian ini.

Jumlah leukosit (WBC) menurun atau leukopenia ditemukan pada sebagian besar sampel penelitian. Hal tersebut dikarenakan sampel yang diambil adalah sampel pasien DBD hari ke-5, jadi masih mengalami fase kritis, yang khas ditandai dengan kondisi leukopenia. ${ }^{10}$ Kondisi leukopenia juga merupakan respon alamiah tubuh untuk melawan infeksi. Hal ini seringkali timbul karena ada penunjukkan ligan kematian "Fas" yang mengimbas kematian sel (apoptosis) leukosit yang terinfeksi, dalam artian tubuh masih memiliki sistem pertahanan yang baik. ${ }^{11}$

Kesemua sampel, baik infeksi primer maupun infeksi sekunder, mengalami demam. Menurut WHO, pola demam yang terjadi pada umumnya bifasik (saddle back fever) dimana mengalami tiga tahap yaitu fase demam (demam tinggi pada awal infeksi), fase kritis (demam mulai turun akan tetapi rawan gejala warning sign), dan fase penyembuhan (demam naik lagi tapi ditandai dengan pulihnya keadaan umum pasien). ${ }^{6}$ Selain itu, hasil test torniquet (Rumple Leede) sampel semuanya positif. Perdarahan lebih banyak terjadi pada infeksi sekunder. Perdarahan pada DBD disebabkan oleh tiga kelainan hemostasis utama, yaitu vaskulopati, kelainan trombosit, dan penurunan kadar faktor pembekuan. ${ }^{9}$ Karena infeksi sekunder merupakan infeksi yang bisa mengarah ke gejala yang lebih berat, maka bisa ditemukan gejala lainnya seperti hepatomegali, efusi pleura, hipoalbuminemia, kulit dingin dan lembab, gelisah dan gejala syok. Sementara pada infeksi primer tidak ditemukan gejala tersebut, hal ini dikarenakan infeksi primer masih bersifat subklinis. ${ }^{5}$ Kesemua sampel, baik infeksi primer maupun sekunder, memenuhi kriteria DBD menurut WHO 2011.

\section{KESIMPULAN}

Pada penelitian ini, dapat diketahui bahwa sampel yang mengalami infeksi sekunder lebih banyak daripada sampel infeksi primer. Semua sampel infeksi primer maupun sekunder, mengalami kondisi trombositopenia. Nilai hematokrit (HCT) normal dengan sampel terbanyak. Nilai leukosit (WBC) yang menunjukkan leukopenia dengan sampel terbanyak. Manifestasi klinis demam dan uji torniquet (+) dialami semua sampel baik infeksi primer maupun sekunder. Manifestasi perdarahan berupa gum bleeding paling banyak muncul, baik pada infeksi primer maupun infeksi sekunder. Pada infeksi sekunder, dapat ditemukan gejala lain seperti hepatomegali, efusi pleura, hipoalbuminemia, kulit dingin dan lembab, gelisah maupun syok.

\section{DAFTAR PUSTAKA}

1. Sari, S. K. \& Aryati. Diagnosis Jangkitan (Infeksi) Virus Dengue dengan Uji Cepat (Rapid Test) IgA Anti-Dengue. Indonesian Journal of Clinical Pathology and Medical Laboratory. 2011; 17 (2), 81-85.

2. Bhaskar, E., Sowmya, G., Moorthy, S., Sundar, V. Prevalence, Patterns, and Factors Associated with Bleeding Tendencies in Dengue. J Infect Dev Ctries. 2015; 9 (1), 105-110. 
3. Yasa, I. W. P. S., Putra, G. A. E. T., Rahmawati, A. Trombositopenia pada Demam Berdarah Dengue. Medicina. 2012; 43:114-121.

4. Dinas Kesehatan Provinsi Bali. Profil Kesehatan 2014. [Online]; 2015. Tersedia di: www.diskes.baliprov.go.id [Diakses 12 Desember 2016).

5. Sastri, N.L.P.P. \& Lestari, A.A.W. Gambaran Hasil Pemeriksaan Darah Lengkap pada Pasien Suspect Infeksi Virus Dengue di Rumah Sakit Surya Husadha Denpasar Februari-Juli 2014. E-Jurnal Medika Udayana. 2016; 7 (5), 1-5.

6. Rahadian, D.H. "Perbedaan Tingkat Pengetahuan Ibu dan Tindakan Pencegahan Demam Berdarah Dengue Di Wilayah Endemis Dan Non Endemis" (Skripsi). Semarang: Universitas Diponegoro; 2012.

7. Bali Post. Kasus Demam Berdarah Meningkat di Empat Kabupaten. [Online]; 2013. Tersedia di: http://balipost. co.id/mediadetail.php? module $=$ detailberitaindex\&kid $=$ 2\&id=76616 [diunduh: 17 November 2013]

8. Badan Pusat Statistik Provinsi Bali. Luas Wilayah, Proyeksi Penduduk, Rasio Jenis Kelamin, dan Kepadatan Penduduk Menurut Kabupaten/Kota di Bali Tahun 2014. [Online]; 2014. Tersediadi:http://bali.bps.go.id/tabel_detail.php?ed= 604003\&od=4\&id=4 [diunduh: 30 Oktober 2014]
9. Rena, N. M. R. A., Utama, S., Parwati T. Kelainan Hematologi Pada Demam Berdarah Dengue. J Peny Dalam. 2009; 10 (3), 218-225.

10. Nopianto, H. "Faktor-Faktor Yang Berpengaruh Terhadap Lama Rawat Inap Pada Pasien Demam Berdarah Dengue Di Rsup Dr. Kariadi Semarang" (Skripsi). Semarang: Universitas Diponegoro; 2012.

11. Juranah, Darwati, M., Arif, M. \& Bahar, B. Uji Hematologi Pasien Terduga Demam Berdarah Dengue Indikasi Rawat Inap. Indonesian Journal of Clinical Pathology and Medical Laboratory. 2011; 17 (3), 139-142.

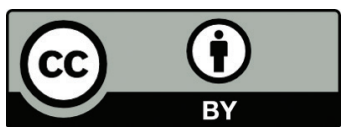

This work is licensed under a Creative Commons Attribution 